Bangladesh J. Plant Taxon. 25(2): 167-173, 2018 (December)

(C) 2018 Bangladesh Association of Plant Taxonomists

\title{
MUSA $\times$ PARAHAEKKINENII (MUSACEAE): A NEW ARTIFICIAL INTERSPECIFIC HYBRID FROM KERALA, INDIA
}

\author{
Komban Parameswaran Smisha and Mamiyil Sabu ${ }^{1}$ \\ Angiosperm Taxonomy and Floristics Division, Department of Botany, \\ University of Calicut, Kerala 673 635, India
}

Keywords: Musa coccinea; Musa haekkinenii; Wild parents; Manual crosses; New artificial hybrid.

\begin{abstract}
Musa $\times$ parahaekkinenii (Musaceae), a new manually crossed interspecific hybrid of two wild parent plants Musa coccinea Andrews (female) and Musa haekkinenii N.S. Lý \& Haev. (male), is described and illustrated. A comparison of characters with its parents and a key to the new hybrid $M . \times$ parahaekkinenii are provided.
\end{abstract}

\section{Introduction}

The Musaceae (Commelinids: Zingiberales) is a tropical family comprising three genera, namely Ensete Horaninow, Musa L. and Musella (Franchet) Wu. Musa L. is the largest genus of the family (ca. 65 species) distributed in tropical Asia from southern India to eastern Himalayas to northern Australia, Sri Lanka and Africa. Globally, bananas (Musa spp.) form the fourth-most important food crop (Novak et al., 2014). Moreover, the bananas have got much attention for their medicinal, ornamental and socio-economic value (Cordeiro et al., 2004; Aziz et al., 2011; Joe and Sabu, 2016). The two new artificial hybrids of Musaceae, Musa $\times$ georgiana Rich. H. Wallace (Wallace and Hakkinen, 2009) and Musa $\times$ formobisiana H.-L.Chiu, C.-T. Shii \& T.-Y.A. Yang. (Chiu et al., 2017) were developed earlier to explore the breeding relevance and ornamental potential value for the banana breeding programmes and landscaping applications.

As part of our studies on reproductive biology of Musaceae with the purpose of breeding evaluation and finding potential ornamental value, intra and intersectional hybridization have been done. The paper focuses on the new artificial hybrid, developed from artificial breeding of the Scarlet Banana M. coccinea Andrews (female parent) and M. haekkinenii N.S. Lý \& Haev. (male parent) which shared the vegetative and floral characters of both the parents and expressed some of its own.

\section{Materials and Methods}

The present study was conducted at Calicut University Botanical Garden $\left(11^{\circ} 25^{\prime} 45^{\prime}\right.$ 'N, $75^{\circ} 45^{\prime} 50^{\prime}$ 'E) during 2013-2016. The stigma receptivity of Musa coccinea (female parent) and pollen viability of $M$. haekkinenii (male parent) were assessed at different time intervals from anthesis to flower closing using MTT (Dafni et al., 2005) and TTC (Shivanna and Rangaswamy, 1992) tests, respectively. Manual cross pollination was done in a period of maximum stigma receptivity and pollen viability which coincides. The self-compatibility was assessed by a method suggested by Dafni et al. (2005). The seed set and seed germination were observed for 3-4 months. The phenological events of new interspecific hybrid were observed with 10 plants of F1 hybrid. Morphometric analysis of vegetative and floral characters was done with a scale and

\footnotetext{
${ }^{1}$ Corresponding author. Email: msabu9@gmail.com
} 
LEICA M80 stereomicroscope. Colour comparison of new hybrid with that of parents was referred by colour code (Kornerup and Wanscher, 1978). Descriptions of a new hybrid and parent plants were given using INIBAP Musa descriptor list (IPGRI-INIBAP/CIRAD, 1996). Photographs were taken with Sony DSC-HX400V digital camera. Voucher specimens were deposited at CALI and MH.

\section{Results and Discussion}

Musa × parahaekkinenii K.P. Smisha \& M. Sabu, hybrid nov.

(Figs 1\&2).

Diagnosis: Musa $\times$ parahaekkinenii differs from the female parent $M$. coccinea in having orange red bracts (vs. scarlet red) and presence of yellow fruits (vs. creamy fruits). The $M . \times$ parahaekkinenii shows distinct characters from the male parent $M$. haekkinenii by the presence of bracts obliquely erect to axis (vs. bracts curving downward). Moreover, the hybrid $M . \times$ parahaekkinenii exhibits the presence of horn-like appendages on lateral lobes of compound tepal. These appendages are present on the five lobes of compound tepal of $M$. coccinea while totally absent in all lobes of compound tepal of M. haekkinenii.

Type: India, Kerala, Malappuram district, Thenhipalam, Calicut University Botanical Garden (1125'45’'N, 75'45'50'E), 09 Dec 2016, K.P. Smisha 147908 (Holotype: CALI; Isotype: MH).

Clump forming; plants slender, herbaceous, suckering freely with 8-10 suckers of $10-15 \mathrm{~cm}$ long, oriented vertically. Mature pseudo-stem slender, $90-100 \mathrm{~cm}$ high, $13-15 \mathrm{~cm}$ in diam. at the base; sap milky. Leaf green, dorsiventral, $100-130 \mathrm{~cm}$ length; petiole $28-30 \mathrm{~cm}$ long, green with sparse brown blotches at the base, petiole canal margins incurved, narrow, 0.6-0.7 cm wide, scarious, clasping pseudo-stem at the base; lamina oblong-lanceolate, $70-100 \times 23.5-24 \mathrm{~cm}$, apex obtuse, margin corrugated, midrib $70-100 \times 0.6-0.7 \mathrm{~cm}$, greyish green adaxially, pale greyish green abaxially, one side rounded and other pointed, adaxial surface dark green and dull, abaxial surface deep green and shiny, insertion point of leaf bases asymmetric on both sides. Inflorescence erect; peduncle 5-8 cm long, 5.0-5.5 cm in diam., glabrous, yellowish cream. Flag leaf with colourful bract like base and leafy apex persistent, $45-55 \mathrm{~cm}$ long. Sterile bracts lanceolate, $20-21 \times 4.0-4.5$ $\mathrm{cm}$, adaxial surface dull, orange red with yellow tinge at base, abaxial surface shiny, orange red with yellow tinge at base, apex acute, greenish, base greyish orange, small shouldered, persistent. Male bracts lanceolate, $11-12 \times 4.3-4.5 \mathrm{~cm}$, bract lifting one at a time, persistent, adaxial surface dull, orange red, abaxial surface shiny, orange red, apex intermediate, green tinted with yellow, base greyish orange, small shouldered, margin not revolute. Female bracts lanceolate, 12.5$13.5 \times 4.0-4.5 \mathrm{~cm}$, adaxial surface dull, orange red, abaxial surface shiny, orange red, apex acute to obtuse, green tinted with yellow, base greyish orange, small shouldered, margin not revolute, lifting one bract at a time, imbricate. Basal flowers female, yellow, 1 flower per bract, 4-7 cm long. Compound tepal 3-4×1.2-2.3 cm, lower half deep yellow and upper half olive green, ribbed on either side, apex 5-lobed, rounded, with one horn-like appendages on lateral lobes, two lobes larger and exserted, $0.1 \times 0.2 \mathrm{~cm}$, middle and lateral lobes curved backward, $0.1 \times 0.2 \mathrm{~cm}$. Free tepal $3.0-3.8 \times 1.0-1.2 \mathrm{~cm}$, ovate, as long as the style, closely appressed to the stigma, translucent, opaque yellow, margin entire, apex corrugated with short acumen, adaxial surface smooth, abaxial surface ribbed. Staminodes 5, lanceolate, creamy yellow, $0.8-1.7 \times 0.1-0.2 \mathrm{~cm}$. Ovary straight, $2.2-4.0 \mathrm{~cm}$ long, lemon yellow, waxy, 3-locular; style straight, $2-3 \times 0.1-0.2 \mathrm{~cm}$, pale yellow with olive green tinge at apex. Stigma yellow, terete, $0.8 \times 0.5 \mathrm{~cm}$. Male flowers yellow, 2 flowers per bract, $4.7-5.0 \mathrm{~cm}$ long. Compound tepal $4.5-5 \times 1.8-2.3 \mathrm{~cm}$, lower half deep yellow and upper half olive green, ribbed on either side, apex 5-lobed, rounded, with horn-like appendages on lateral lobes, three middle lobes larger and exserted, $0.2 \times 0.1 \mathrm{~cm}, 3$ central lobes curved backward, $0.1 \times 0.1 \mathrm{~cm}$. Free tepal $4.5-4.7 \times 1.0-1.3 \mathrm{~cm}$, ovate, $3 / 4^{\text {th }}$ of compound tepal, translucent, opaque 
yellow, margin entire, apex corrugated with short acumen, adaxial surface smooth, abaxial surface ribbed. Stamens 5, 4.2-4.3 cm long; anther greyish yellow, fertile, $1.8-2 \times 0.05-0.1 \mathrm{~cm}$; filament

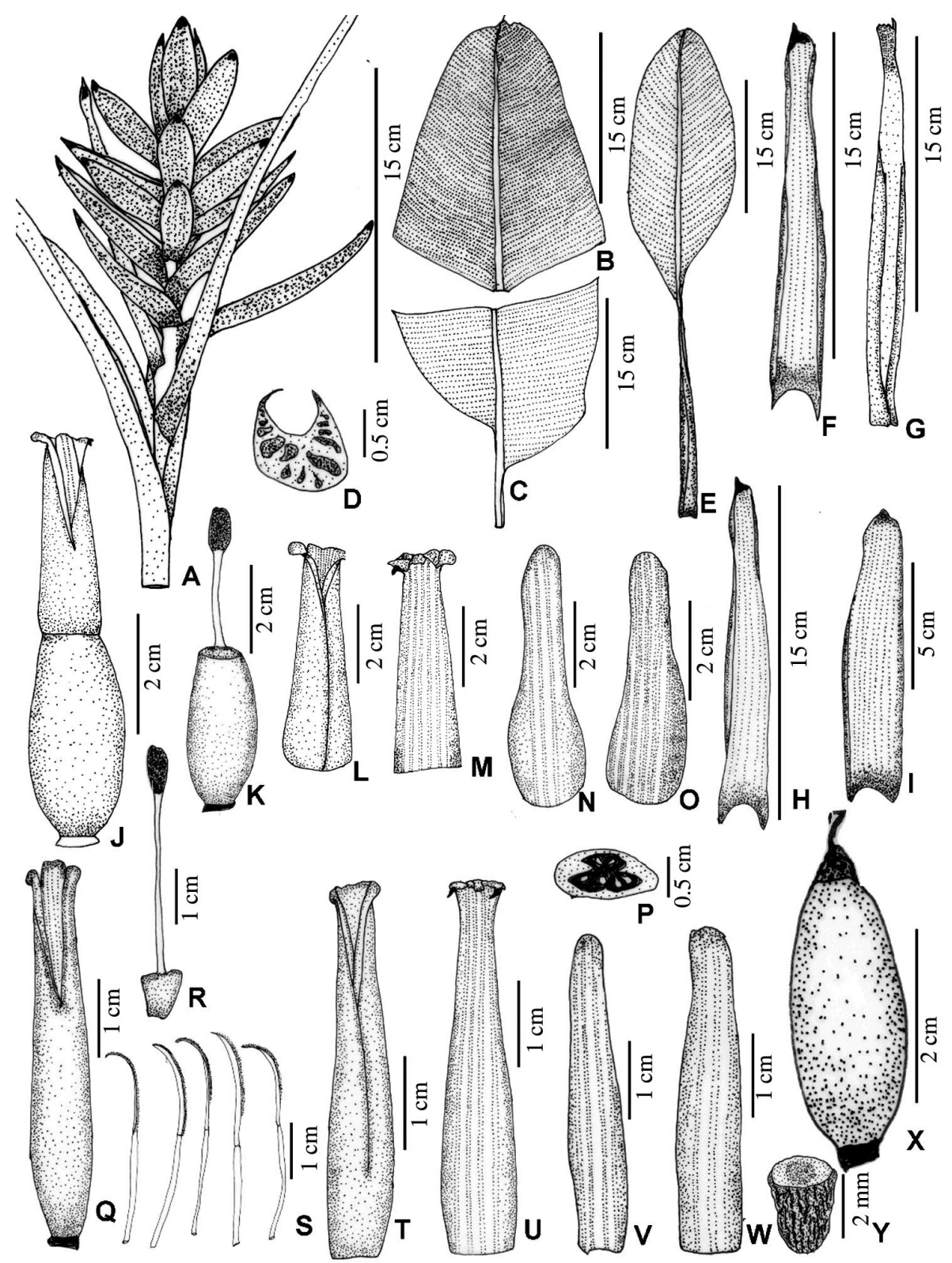

Fig. 1. Illustration of Musa $\times$ parahaekkinenii hybrid nov. A. Inflorescence; B. Leaf apex; C. Leaf base; D. Cross-section of petiole; E. Flag leaf; F\&G. Sterile bracts; H. Female bract; I. Male bract; J. Female flower; K. Ovary with style and stigma; L\&M. Compound tepals; N\&O. Free tepals; P. Cross-section of ovary; Q. Male flower; R. Rudimentary ovary with style and stigma; S. Stamens; T\&U. Compound tepals; V\&W. Free tepals; X. Fruit; Y. Seed. 


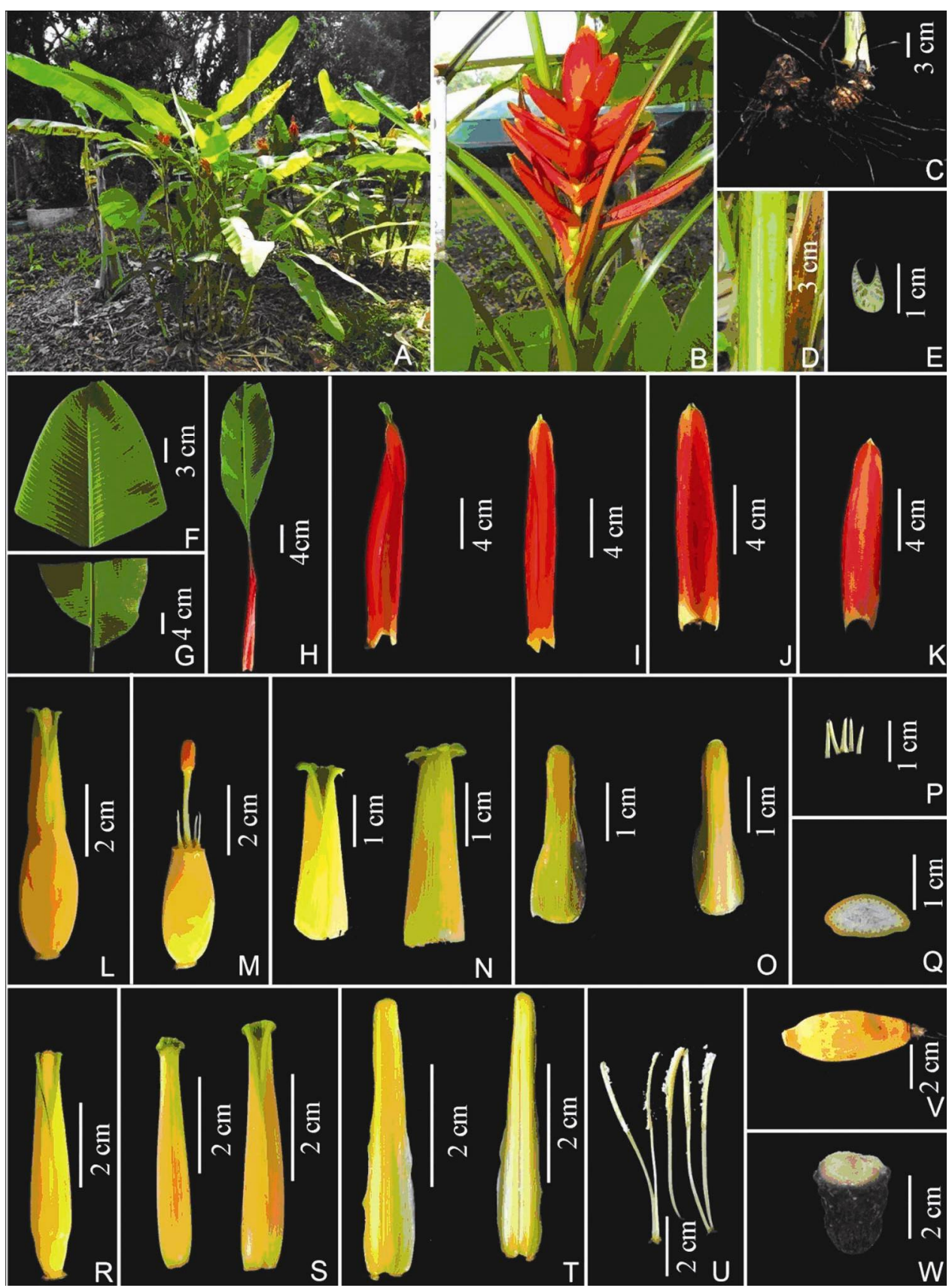

Fig. 2. Musa $\times$ parahaekkinenii hybrid nov. A. Habit; B. Inflorescence; C. Corm; D. Pseudostem; E. Crosssection of petiole; F. Leaf apex; G. Leaf base; H. Flag leaf; I. Sterile bracts; J. Female bract; K. Male bract; L. Female flower; M. Ovary with style and stigma; N. Compound tepals; O. Free tepals; P. Staminodes; Q. Cross-section of ovary; R. Male flower; S. Compound tepals; T. Free tepals; U. Stamens; V. Fruit; W. Seed. 
1.6-2.5 $\times 0.1-0.2 \mathrm{~cm}$, light yellow. Style rudimentary, straight, $3.5-4.4 \times 0.1-0.2 \mathrm{~cm}$, pale yellow with olive green tinge at apex. Stigma rudimentary, terete, yellowish orange, narrowly oblong, $0.6-0.7 \times 0.3-0.4 \mathrm{~cm}$. Ovary rudimentary, oblong, $0.5-0.7 \times 0.4-0.8 \mathrm{~cm}$, pale yellow, waxy. Fruit berry, 1 per bract, mature fruit narrowly oblong, $5.0-6.5 \mathrm{~cm}$ long, yellow, not waxy, straight, bear persistent floral relicts; $3.5-4.0 \mathrm{~cm}$ long. Seeds numerous, cylindrical, brown, warty, $1.5-2.0 \mathrm{~cm}$ long.

Etymology: The epithet has been named for the bract colour that resemblance with the male parent (M. haekkinenii) at the first appearance.

\section{Key to the new hybrid Musa $\times$ parahaekkinenii and its parents}

1. Bracts obliquely upward to axis.

2

- Bracts curving downwards to axis.

M. haekkinenii

2. Horn-like appendages only on lateral lobes of compound tepal; bracts orange red.

- Horn-like appendages on all lobes of compound tepal; bracts M. coccinea scarlet red.

Table 1. Comparison of characters of Musa $\times$ parahaekkinenii hybrid nov. with its parents.

\begin{tabular}{llll}
\hline Characters & M. haekkinenii & M. $\times$ parahaekkinenii & M. coccinea \\
\hline Plant height $(\mathrm{cm})$ & $250-300$ & $80-110$ & $150-200$ \\
Sap & Watery & Milky & Watery \\
Sucker number & $8-13$ & $9-12$ & $8-10$ \\
$\begin{array}{l}\text { Petiole canal margins } \\
\text { Leaf base }\end{array}$ & Wide, erect & Narrow, erect & Narrow, erect \\
& One side rounded, & Both side pointed & Rounded \\
one pointed & & \\
Female/Male bract & Persistent, curving & Persistent, obliquely & Persistent, obliquely \\
behaviour & downward to axis & upward to axis & upward to axis \\
Female/Male bract & Bright orange red on & Bright orange red on & Deep scarlet red on \\
& both sides & both sides & adaxial and abaxial side \\
Female/Male flowers & $1-4$ & $1-2$ & $1-2$ \\
per bract & & Narrowly flat & Narrowly flat \\
Stigma shape & Flat & Present only on lateral & Present on all lobes of \\
Appendage & Absent & lobes of compound tepal & compound tepal \\
& & 1, straight & $1-2$ straight \\
No. of fruit/s per & $3-4$, straight & & \\
bract and shape & & & \\
\hline
\end{tabular}

The petiole canal margins are clasping, ovary deep yellow and the seeds barrel-shaped and warty in the parents and the artificial hybrid.

A new hybrid Musa $\times$ parahaekkinenii, developed here by manual cross pollination is highly relevant for breeding application and to explore the potential ornamental value. The reciprocal cross between $M$. haekkinenii (female parent) and $M$. coccinea (male parent) also resulted in fruit set and seed production. Hybridization experiments of $M$. coccinea (female parent) with male parents of $M$. beccarii, M. ornata, M. siamensis, M. laterita, M. velutina and M. markkuana did not result in any fruit set. But the cross between M. haekkinenii (female parent) and M. beccarii (male parent) resulted in both fruit and seed set. 
Musa coccinea is distributed in Indochina and China (Leong-Škorničková and Gallick, 2012). The species is remarkable for its highly attractive scarlet red bracts. The bract is oriented obliquely erect to axis and persistent that improves the potential ornamental value of the species. On the other hand, Musa haekkinenii is a native wild banana of Vietnam and known only under cultivation (in Calicut University Botanical Garden, Kerala, India and Suriana Botanic Garden, Penang, Malaysia) today. The centre of origin of the species is northern Vietnam and no wild population of it so far reported. Its existence in the wild is still uncertain. It was recognized as a Data Deficient species according to IUCN Red List categories and criteria (Lý et al., 2012). The plant has a potential ornamental value because of the presence of highly attractive orange red persistent bract.

The new interspecific hybrid $M . \times$ parahaekkinenii which express intermediate characters of M. coccinea (ㅇ) and M. haekkinenii $(\hat{\partial})$ and exhibits new characters also. The basal unisexual female flowers are fertile with receptive stigma and unisexuality is recognized as a unique adaptation for cross pollination. The male flowers are fertile with pollen grain production and recognized as a self-compatible hybrid. However, the new hybrid significantly adds the ornamental value because of the presence of highly attractive persistent bracts and flowers of inflorescence which lasts up to 3-4 months. Currently, many newly explored wild Musa species are used as staple food, medicine and ornamentals and also got socio-economic relevance. So, the interspecific hybridization between wild species has an immense value for breeding purposes and to explore the aspects of genetic variability which form the basis of genetic diversity.

\section{Acknowledgements}

The authors thank Kerala State Council for Science, Technology and Environment (KSCSTE), providing necessary funds for research work (Order No. 402/2015/KSCSTE dated 18.08.2015).

\section{References}

Aziz, N.A.A., Ho, L.-H., Azanari, A., Bhat, R., Cheng, L.-H. and Ibrahim, M.N.M. 2011. Chemical and functional properties of the native banana (Musa acuminata $\times$ balbisiana Colla cv. Awak) pseudo-stem and pseudo-stem tender core flours. Food Chem. 128: 748-753.

Chiu, H.-L., Shii, C.-T. and Yang, T.Y.A. 2017. Musa $\times$ formobisiana (Musaceae), a new interspecific hybrid banana. Taiwania 62: 147-150.

Cordeiro, N., Belgacem, M.N., Torres, L.C. and Moura, J.C.V.P. 2004. Chemical composition and pulping of banana pseudo-stems. Ind. Crops Prod. 19: 147-154.

Dafni, A., Kevan, P.G. and Husband, B.C. 2005. Practical Pollination Biology. Enviroquest Ltd., Canada, pp. 1-590.

IPGRI-INIBAP/CIRAD. 1996. Description for Bananas (Musa spp.). International Plant Genetic Resources Institute, Rome, Italy/ International Network for the Improvement of Banana and Plantain, Montpellier, France/ Centre de Cooperation Internationale en Rechereche Agronomique pour le Development, Montpellier, France, pp. 1-58.

Joe, A. and Sabu, M. 2016. Wild ornamental bananas in India: an overview. Sourth Ind. J. Biol. Sci. 2: 213-221.

Kornerup, A. and Wanscher, J.H. 1978. Methuen Handbook of Colour, $3^{\text {rd }}$ edn. Methuen, London, pp. 1-252.

Leong-Škorničková, J. and Gallick, D. 2012. The Ginger Garden. National Parks Board Singapore Botanic Garden, Singapore, $114 \mathrm{pp}$.

Lý, N.S., Lê, C.-K., Triệu, T.-D., Haevermans, A., Lowry II, P.P. and Haevermans, T. 2012. A distinctive new species of wild banana (Musa, Musaceae) from northern Vietnam. Phytotaxa 75: 33-42. 
Novák, P., Hřibová, E., Neumann, P., Kobližková, A., Doležel, J. and Macas, J. 2014. Genome wide analysis of repeat diversity across the family Musaceae. PLoS ONE 9: e98918.

Shivanna, K.R. and Rangaswamy, N.S. 1992. Pollen Biology: A Laboratory Manual. Narosa Publishing House, New Delhi, pp.1-199.

Wallace, R. and Häkkinen, M. 2009. Musa $\times$ georgiana, a new intersectional hybrid banana with edible banana breeding relevance and ornamental potential. Nordic J. Bot. 27: 182-185.

(Manuscript received on 23 October 2017; revised on 7 November 2018) 